\title{
Notes on the Emergence of New Semitic Roots in the Light of Compounding
}

\author{
LUTZ EDZARD (University of Erlangen-Nürnberg / University of Oslo)
}

\begin{abstract}
Independently of the question as to whether bi- or triradical roots have historical preponderance in Semitic, there are clear cases of Semitic verbal and nominal roots that have emerged through a process of compounding or integration of additional elements (verbal or nominal affixes and even prepositions). In this paper, an attempt will be made to establish a hierarchical typology of such processes of morphophonological re-analysis, in both historical and modern times.
\end{abstract}

Key words: affix, re-analysis, root, compounding

\section{Introduction}

It has long been recognized that new roots in Semitic can emerge through the re-analysis of verbal or nominal affixes. On the one hand, there has been the theory of "matrices et étymons", propagated notably by Georges Bohas (e.g., BOHAS 2000) and a number of his pupils, which builds on the observation that roots with two common consonants and a homorganic, but different third consonant, often share a common semantics. Christopher Ehret (notably EHRET 1995) has developed this theory even further, in trying to reconstruct uniconsonantal semantic core elements at an early stage of Afroasiatic. This well-known line of thought will not be pursued here (for an overview of the pros and cons, cf. e.g., ZABORSKI 1991). Rather, with a focus on Arabic and Hebrew, I will give an overview of various processes that can be described as "compounding", which involve either the integration of grammatical morphemes-verbal and nominal affixes, including prepositions-or the creation of new roots by exploiting acronyms or the conjunction of clipped elements, captured by the Arabic term naht, literally 'sculpture'.

\section{Root formation through compounding}

\subsection{Integration of grammatical morphemes}

Adam MEZ (1906) was among the first to present relevant examples in Arabic, an example being the root $\sqrt{ } \mathrm{s}-\mathrm{b}-\mathrm{q}$ in Arabic sabaqa 'to leave behind', which was explained as resulting from the compounding of the causative afformative $s$ - (also present in the Arabic form X, 
together with the reflexive afformative $-t-$ ) and the root $\sqrt{ } \mathrm{b}-\mathrm{q}-\mathrm{y}$ in Arabic baqiya 'to remain behind'. The productivity of such processes can also be demonstrated by a modern Arabic neologism. Next to the form IV of the root $\sqrt{ } \mathrm{s}-1-\mathrm{m}$ Paslama (IPF yuslimu) 'to render onesolf in security, become a Muslim', a verb Paslama (IPF yu?aslimu) with the meaning 'to islamize' has emerged (in possible analogy to verbs such as Pamraka 'to americanize'), which synchronically represents the root $\sqrt{ }$ P-s-1-m.

This kind of re-analysis is not specific to Arabic. HUEHNERGaRD (2014: 14), based on KURYŁOWICZ (1973: 7) and others, adduces the common-Semitic verb $\sqrt{ }$ š-k-n, Akkadian šakānum 'to place, put, set'. As the Central Semitic cognates of šakānum, Hebrew šăkan/ šăkēen, Aramaic šzken, and Arabic sakana 'to dwell' are intransitive, HUEHNERGARD assumes two roots in this context: the transitive Akkadian root can be explained to derive from an $\check{s}$-causative form of the verb $\sqrt{ } \mathrm{k}$-w-n 'to be firm, fixed', whereas the intransitive Central Semitic verbs with the meaning 'to dwell' derive directly from a root $\sqrt{ } \mathrm{s}-\mathrm{k}-\mathrm{n}$ (Ugaritic features both roots). I would suggest that "to dwell" could also be rephrased in a transitive way as "to make a living" or the like and thus could also be explained an an original causative. Another example of this kind offered by MEZ (1906) is the Arabic verb $\sqrt{ } \mathrm{r}$-t-S rataSa 'to graze', derived from form VIII of the common Semitic root $\sqrt{ } \mathrm{r}$ - $\mathrm{S}-\mathrm{y}$. The same phenomenon surfaces in the nominal form taqwā 'belief', derived from form VIII ittaq $\bar{a}$ of the verbal root $\sqrt{ } \mathrm{w}-\mathrm{q}-\mathrm{y}$. A comparable Hebrew case is presented by the secondary root $\sqrt{ } \mathrm{t}$-h-l, attested in the hif؟īl-binyan as hithīl 'to begin', ultimately deriving from the root $\sqrt{ }$ h-l-1 with the same meaning in the attested in the hifCîl-binyan as hệhell. Diachronically, a comparable process can be observed in the re-analysis of the Arabic noun madina 'city', which historically constitutes a noun of the pattern $/ \mathrm{maC}_{1} \mathrm{C}_{2} \mathrm{a} \mathrm{C}_{3} \mathrm{a}$ / based on the root $\sqrt{ } \mathrm{d}-\mathrm{y}-\mathrm{n}$, and which synchronically functions as a noun of the pattern $/ \mathrm{C}_{1} \mathrm{aC}_{2} \overline{\mathrm{i}} \mathrm{C}_{3} \mathrm{a} /$, based on the root $\sqrt{ } \mathrm{m}$-d-n. Accordingly, the historical plural form is madāin, whereas the modern plural form is mudun. ${ }^{1}$ HUEHNERGARD (2014: 10) cites the Biblical Hebrew plural form dalātot $\underline{t}$ 'doors', which was generated by re-analyzing the final feminine $t$ of the singular delet 'door' as a root consonant.

In modern Hebrew, such processes are especially productive. USSISHKIN (1999: 407) lists, among others, the following examples, in which nominal affixes are integrated into new expanded roots. In most cases, quadri-radical roots emerge, which are fitted into the piৎ̧el or hitpaY̧el binyanim; in the case of the noun (tertiae infirmae) qașe ( $\sqrt{ } \mathrm{q}-\mathrm{s}-\mathrm{h})$, the hifGil binyan is used:

$\begin{array}{lll}\text { root } & \text { surface } & \text { gloss } \\ \sqrt{ } \mathrm{q}-\mathrm{m}-\mathrm{s} & \text { hitqames } & \text { 'to be a miser' } \\ \sqrt{ } \mathrm{q}-\mathrm{s}-\mathrm{h} & \text { qașe } & \text { 'edge' } \\ \sqrt{ } \mathrm{m}-\mathrm{s}-\mathrm{h} & \text { mișa } & \text { 'to treat exhaustively' } \\ \sqrt{\mathrm{x}-\mathrm{z}-\mathrm{q}} & \text { hịxziq } & \text { 'to hold' } \\ \sqrt{\mathrm{s}-\mathrm{p}-\mathrm{r}} & \text { safar } & \text { 'to count' }\end{array}$

1 WEHR's dictionary lists the noun madina under both $\sqrt{ }$ d-y-n- and $\sqrt{ }$ m-d-n. 
New Semitic roots in the light of compounding

\begin{tabular}{|c|c|c|c|c|}
\hline derived form & gloss & new root & surface & gloss \\
\hline qams + an & 'miser' & $\sqrt{\text { q-m-ṣ-n }}$ & hitqamșen & 'to be a miser' \\
\hline$q i s ̣+o n+i$ & 'extreme' & $\sqrt{ }$ q-ș-n & hiqșin & 'to exaggerate' \\
\hline$t a+m s+i t$ & 'summary’ & $\sqrt{ }$ t-m-ṣ-t & timșet & 'to sum up' \\
\hline$t a+x z u k+a$ & 'maintenance' & $\sqrt{t-\underline{X}-z-q}$ & tixzzeq & 'to maintain' \\
\hline$m i+$ spar & 'number' & $\sqrt{ }$ m-s-p-r & misper & 'to enumerate' \\
\hline
\end{tabular}

Next to verbal and nominal affixes, prepositions also can be integrated in newly emerging roots. Among the more prominent cases figures Arabic $\check{g} \bar{a} ? a(\sqrt{ } \mathrm{g}-\mathrm{y}-\mathrm{P})$ 'to come' $+b i$ - 'in, with', which in Arabic dialects surfaces as $\check{g} \bar{a} b(\sqrt{ } \breve{\mathrm{g}}-\mathrm{y}-\mathrm{b})$ 'to bring'. A similar case already occurred in Classical Syriac, where the verbal root $\sqrt{n-t-n}$ 'to give' is typically construed with the dative marker $l o$ - 'to', resulting in a new root $\sqrt{ }$ n-t-l 'to give' (cf., e.g., EDZARD 2011).

\subsection{Root formation by exchange of a root consonant}

Both new nouns, adjectives and verbs can emerge as the result of blending and (preceding) clipping (see below section 2.5). Of special interest is the case, where only one letter of one part of the blend replaces another letter in the other part, thus creating a new root. In the

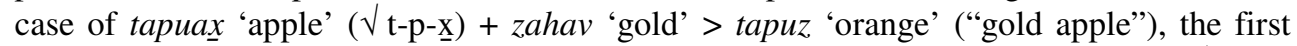
letter zayin of zahav replaces the last letter xet of tapuax, thus creating the new root $\sqrt{ } \mathrm{t}-\mathrm{p}-\mathrm{z}$. In the case of pele(?) 'wonder' + telefon 'telephone' > pele(?)fon 'smart phone', the firt letter pe of pele(?) replaces the first letter tet of telefon. And in the case of yadid 'friend' + zayin 'penis' > yaziz 'lover' ("penis friend"), the first letter zayin of zayin (in itself historically a "polite" form using just the first letter of the word zanav 'tail') twice replaces the letter dalet of yadid. ${ }^{2}$

\subsection{Root formation via acronyms}

Acronyms as new roots occur in modern Arabic, notably in religious, political, and technical context. As in many European languages, one can observe a tendency to create acronyms that simultaneously have a meaning of their own. The following two political examples are prominent:

$$
\begin{array}{ll}
\text { fath }(<\mathrm{f}-\mathrm{t}-\mathrm{h}>) & \text { harakat at-taḥrīr al-filasțin̄īya } \\
\text { ḥamās }(<\mathrm{h}-\mathrm{m}-\overline{\mathrm{a}}-\mathrm{s}>): & \text { harakat al-muqāwama al-Pislāmīya }
\end{array}
$$

'Palestinian liberation movement'

'Islamic revolt movement'

In the first example fath, the order of the constituents $(<\mathrm{h}-\mathrm{t}-\mathrm{f}>)$ is reversed, in order to yield the meaning "conquest" and to avoid the meaning "slow death". ${ }^{3}$ The second example hamās in itself means "rage, enthusiasm".

2 Cf. BOLOZKY 1999: 217.

3 Cf. BLAU 1981: 174. 
Religion constitutes another realm where a number of new roots based on acronymity have emerged. The following list of nouns is due to LARCHER (2010):

\begin{tabular}{|c|c|c|}
\hline root & surface & base \\
\hline $\begin{array}{l}\sqrt{ } \text { ğ-G-f-d / } \\
\sqrt{ } \text { ğ-G-f-1 }\end{array}$ & $\begin{array}{l}\text { ğąfada / } \\
\text { ğaffala }\end{array}$ & ğuSiltu fidā-ka 'may I be made your ransom!' \\
\hline$\sqrt{ }$ he-s-b-1 & hasbala & hasb-iya llāh 'God suffices me!' \\
\hline $\begin{array}{l}\sqrt{ } \text { h-w-q-1 / } \\
\sqrt{\text { ḥ-w-1-q }}\end{array}$ & $\begin{array}{l}\text { hawqala / } \\
\text { ḩawlaqa }\end{array}$ & $\begin{array}{r}\text { lā ḥawla wa-lā quwwata Pillā bi-llāh 'power and force is } \\
\text { only in God' }\end{array}$ \\
\hline$\sqrt{ }$ h-y-S-1 & haySala & $\begin{array}{r}\text { hayya Salā ș-ṣalāti, hayya Salā l-falāh 'come to prayer, } \\
\text { come to salvation!' }\end{array}$ \\
\hline$\sqrt{ } \mathrm{d}-\mathrm{m}-\mathrm{S}-\mathrm{z}$ & damৎaza & Padāma llāhu Sizza-ka 'may God make endure your power!' \\
\hline$\sqrt{ }$ s-b-ḥ-1 & sabhala & subhāana llāh 'glory be to God!' \\
\hline$\sqrt{ } \mathrm{s}-\mathrm{m}-\mathrm{C}-1$ & samৎala & (as-)salām(u) Salay-kum 'peace be with you!' \\
\hline$\sqrt{ }$ t-1-b-q & talbaqa & Pațāla llāhu baqāîa-ka 'My God extend your life!' \\
\hline$\sqrt{ }$ k-b-t- $\subseteq$ & kabtaৎa & $\begin{array}{r}\text { kabata llāhu l-Saduww (or Saduwwa-ka) 'may God crush } \\
\text { the/your enemy' }\end{array}$ \\
\hline $\begin{array}{l}\sqrt{ } \mathrm{m}-\check{s}-\mathrm{P}-1 / \\
\sqrt{ } \mathrm{m}-\check{s}-\mathrm{k}-\mathrm{n}\end{array}$ & $\begin{array}{l}\text { mašrala / } \\
\text { maškana }\end{array}$ & $m \bar{a}$ šā?a llāh (kāna) 'what God will (obtains)' \\
\hline $\begin{array}{l}\sqrt{ } \text { h-y-1-1/ } \\
\sqrt{ } \text { h-1-1-1 }\end{array}$ & $\begin{array}{l}\text { haylala / } \\
\text { hallala }\end{array}$ & lā Pilāha Pillā llāh 'there is no god except God' \\
\hline
\end{tabular}

Acronyms likewise abound in modern Hebrew. ${ }^{4}$ Military-political as well as cultural terms in general often follow this pattern. Even the most famous philosopher in Jewish history, Maimonides, is mostly referred to under the form of an acronym, rambam $(<\mathrm{r}-\mathrm{m}-\mathrm{b}-\mathrm{m}>)$, reflecting the initial letters of rav moše ben maymon 'Maimonides'. Here are a few wellknown examples:

$\begin{array}{ll}\text { tanax }(<\mathrm{t}-\mathrm{n}-\mathrm{k}>): & \text { tora nevi?im ketuvim 'Tora-Prophets-Scriptures' } \\ \text { Peșel }(<\mathrm{P}-\mathrm{s}-\mathrm{l}>): & \text { Pirgun șevåi lePumi 'National Armed Organization' } \\ \text { șahal }(<\mathrm{s}-\mathrm{h}-\mathrm{l}>): & \text { șeva?-hagana le-yisraPel 'Israel[i] Defense Forces' } \\ \text { Pašaf }(<\mathrm{P}-\mathrm{s}-\mathrm{p}>): & \text { ha-Pirgun le-šixrur falesțin 'PLO' } \\ \text { rambam }(<\mathrm{r}-\mathrm{m}-\mathrm{b}-\mathrm{m}>): & \text { rav moše ben maymon 'Maimonides' }\end{array}$

Acronyms can develop to fully productive roots, as happened in the case of $\sqrt{ } \mathrm{d}-\mathrm{w}-\underline{\mathrm{x}} \mathrm{duax}$ 'report' (properly din ve-xešbon 'law and accounting'), from which one can derive the verb divax 'to report' and davax 'reporter. A comparable examples is the English noun tip (reward for good service), an acronym derived from 'to insure promptness', from which one has derived the verb to tip.

4 For clipping and acronymy, cf. KREIDLER 2000.

jais • 17 (2017): 407-414 


\subsection{Root formation via clipping and blending}

In Arabic, root formation via clipping and blending has been an age-old phenomenon known under the term naḥt, literally 'sculpture'. The grammarian SAbd al-Qādir alMagribī, for instance, suggests the following classification of hybrid forms in his treatise al-ištiqāq wa-t-taৎrīb (cf. STETKEVYCH 1970: 49 f.): ${ }^{5}$

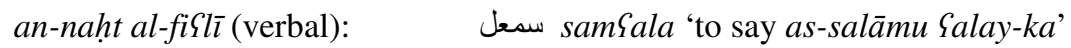

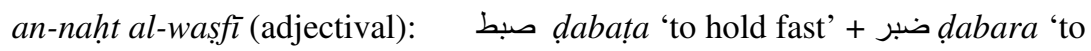

$$
\begin{aligned}
& \text { jump' > dibaṭr 'strong' (said of a lion) }
\end{aligned}
$$

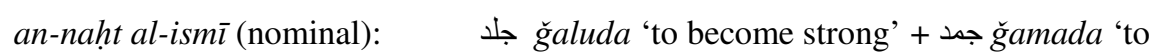

$$
\begin{aligned}
& \text { become firm' > جلمود ğulmūd 'big rock' }
\end{aligned}
$$

an-naḥt an-nisbī (relational): طبرخزي tabarhazì 'belonging to Tabaristan and Khwarizm'

In all cases, either new quadri-literal or quinqui-literal roots emerge, to wit $\sqrt{ } \mathrm{s}-\mathrm{m}-\mathrm{S}-1, \sqrt{ }$ di-b-t-r, $\sqrt{ }$ ğ-l-m-d, and $\sqrt{ }$ t-b-r-h-z.

Modern counterparts include examples such as kahrabā? 'electricity' + mag்nātīs 'magnet' > kahratas 'electro-magnetism'. An especially interesting case is the neologism șaygam 'phoneme', derived by blending șìga 'form' + șawt 'sound', in which the European morpheme -eme is imitated, as in the more usual form sawtam 'phoneme'. 6

The term $r a(?) s m a \bar{l}$ 'capital' represents an interesting case, an annexation synchronically re-analyzed as a compound, having a precursor already in Qur?ānic ruP̄usu ?amwāli-kum 'your wealth' (Q 2:279). The re-analysis as a compound is clearly established by the attested modern plural form rasāmil 'estates', reflecting a new root $\sqrt{ }$ r-s-m-1.

The formation of new roots through a process of clipping and blending is especially productive in modern Hebrew. Here is a selection of examples (cf., e.g., EDZARD 2006):

\begin{tabular}{|c|c|c|}
\hline qol 'sound' + noas 'motion' & $>$ & qolnoas 'cinema' \\
\hline migdal 'tower' + ?or 'light' & $>$ & migdalor 'lighthouse' \\
\hline midraxa 'pavement' + rexov 'street' & $>$ & midrexov 'pedestrian street' \\
\hline kadur 'ball' + regel 'foot' & $>$ & kaduregel 'football' \\
\hline rakevet 'train' + kevel 'cable' & $>$ & rakevel 'cable car' \\
\hline $\begin{array}{l}\text { number + noun }([\mathbf{N u m N}] \mathbf{N}): \\
\text { tlat (aram.) 'three' + ?ofan 'wheel' }\end{array}$ & $>$ & tlat?ofan 'tricycle' \\
\hline $\begin{array}{l}\text { noun }+ \text { adjective }([\mathbf{N A d j}] \mathbf{N}) \text { : } \\
x a y \text { 'living creature' }+d a q \text { 'tender' }\end{array}$ & $>$ & xaydaq 'bacterium' \\
\hline
\end{tabular}

5 Cf. also GRÜNERT 1893.

6 Cf. VERSTEEGH 2001: 183. 


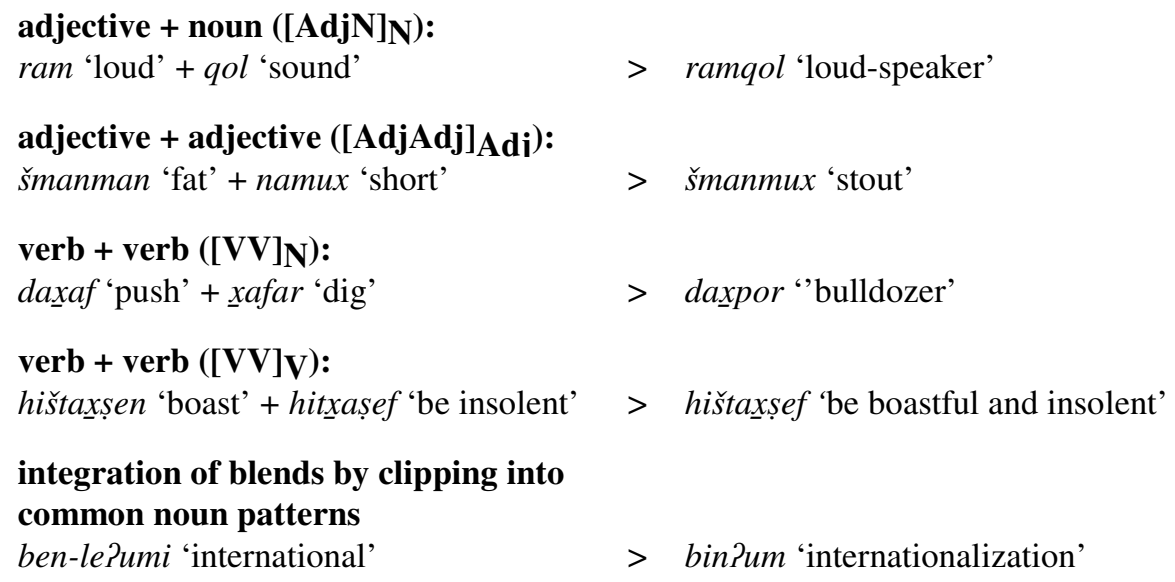

$>$ bin?um 'internationalization'

Both older and more recent varieties of Aramaic feature re-analysis of annexations as compounds. In Syriac, the annexation $b \bar{e} \underline{t} q \underline{b} \bar{u} r \bar{a}$ '[house-of] tomb' is assigned a plural form marked at the right edge, $b \bar{e} \underline{t} q \underline{b} \bar{u} r \bar{e}$ 'tombs', and the annexation šetesst $\underline{t} \bar{a}$ (status constructus

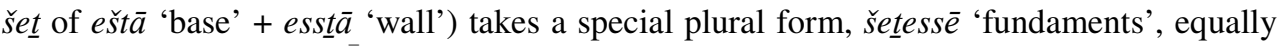
marked at the right edge. ${ }^{7}$

JASTROW (1993: 190, 222) mentions a few compound formations in Turoyo (modern Eastern Aramaic) as the following ones:

$$
\begin{aligned}
& \operatorname{bar} \text { (st. cs.) 'son' + ḥmóho 'father-in-law' } \\
& \operatorname{rīs} \text { (st. cs.) 'head' + dáyro 'monastery' }
\end{aligned}
$$

Such compounding processes also occur in Ethio-Semitic. Amharic adjective-noun phrases occasionally function as compounds, e.g., kaft 'open' + ?af 'mouth' > kaftaf 'foolish' ("openmouthed"). Amharic also features some true blends, e.g., dämoz 'salary', representing the concatenation of däm 'blood' and wäz 'sweat' (necessary ingredients for making a living). ${ }^{8}$

\section{Conclusion}

Compounding and blending, while being less frequent than in Indo-European languages, nevertheless have emerged as powerful mechanisms in Semitic. This observation also pertains to "compound roots" or expanded roots, i.e., newly emerging Semitic roots, in which nominal prefixes, prefixes of diatheses, or even prepositions governed by the respective verb are integrated into the new root. ${ }^{9}$ This question is touched upon here here without prejudice to the question of "original" bilateralism vs. trilateralism in Semitic roots. ${ }^{10}$

7 Cf. NÖLDEKE 1898: 83f.

8 Cf. SHIMELIS 2014: 213.

9 Cf., e.g., MEZ 1906 and EDZARD 2011.

10 Cf., e.g., ZABORSKI 1991.

jais • 17 (2017): 407-414 


\section{References}

BEzold, Carl (ed.). 1906. Orientalische Studien: Theodor Nöldeke zum siebzigsten Geburtstag (2. März 1906). Gießen: Töpelmann.

Blau, Joshua. 1981. The Renaissance of Modern Hebrew and Modern Standard Arabic: Parallels and Differences in the Revival of two Semitic Languages. Berkeley, Los Angeles: University of California Press.

BolOZKY, Shmuel. 1999. Measuring Productivity in Word Formation: The Case of Israeli Hebrew. Leiden: Brill.

BoHas, Georges. 2000. Matrices et étymons: Développements de la théorie. Lausanne: Editions du Zèbre.

BooIJ, Geert, Christian Lehmann, and Joachim Mugdan (eds.). 2000. Morphologie: Ein internationales Handbuch zur Flexion und Wortbildung. Berlin, New York: de Gruyter.

EDZARD, Lutz. 2006. "Some aspects of compound formations in modern Semitic". In: EDZARD \& RETSÖ (eds.) 2006: 132-154.

- . 2011. "Die SIG 7. ALAN = Nabnītu-Liste und das Konzept der semitischen Wurzel". Zeitschrift der Deutschen Morgenländischen Gesellschaft, 161.1: 17-37.

- and Stephan GuTH (eds.). 2010. Verbal festivity in Arabic and other Semitic languages: Proceedings of the Workshop at the Universitätsclub Bonn on January 16, 2009. Wiesbaden: Harrassowitz.

- and John Huehnergard (eds.). 2014. Proceedings of the Oslo-Austin Workshop in Semitic Linguistics, Oslo, May 23 and 24, 2013. Wiesbaden: Harrassowitz.

- and Jan RETSÖ (eds.). 2006. Current Issues in the Analysis of Semitic Grammar and Lexicon II. Wiesbaden: Harrassowitz.

EHRET, Christopher. 1995. Reconstructing Proto-Afroasiatic (Proto-Afrasian): Vowels, Tone, Consonants, and Vocabulary. Berkeley: University of California Press.

GRÜNERT, Max. 1893. "Die Mischwörter im Arabischen (Quellenbeiträge zur Kenntniss des 'naḥt')". In: Actes du Huitième Congrès International des Orientalistes, tenu en 1889 à Stockholm et à Christiania [Oslo]. Deuxième partie, 133-172. Leiden: Brill.

HUEHNERGARD, John. 2014. "Reanalysis and new roots: an Akkadian perspective". In: EDZARD \& HUEHNERGARD (eds.) 2014: 9-27.

JASTROW, Otto. 1993. Laut- und Formenlehre des neuaramäischen Dialekts von Mīdin im Țūr 'Abdīn. 4th edn. Wiesbaden: Harrassowitz.

KAYE, Alan (ed.). 1991. Semitic Studies in Honor of Wolf Leslau on the Occasion of His Eighty-Fifth Birthday. 2 vols. Wiesbaden: Harrassowitz.

KREIDLER, Charles. 2000. "Clipping and acronymy”. In: BooIJ et al. (eds.) 2000: 956-963.

KuRYŁowicz, Jerzy. 1973. Studies in Semitic Grammar and Metrics. London: Curzon. Translation and revision of L'apophonie en sémitique (1961).

LARCHER, Pierre. 2010. "Formules et dérivés « formulatifs » en arabe”. In: EDZARD \& GuTH (eds.) 2010: 43-57.

MEZ, Adam. 1906. “Über einige sekundäre Verben im Arabischen”. In: BEZOLD (ed.) 1906: 249-54.

MonTEIL, Vincent. 1960. L'arabe moderne. Paris: Librairie Klincksieck.

NöLDEKE, Theodor. 1898. Kurzgefaßte syrische Grammatik. 2nd edn. Leipzig: Tauchnitz.

SHIMELIS, Mazengia. 2014. Nominalization via Verbal Derivation in Amharic, Tigrinya and Oromo: A Contrastive Study. Ph.D. dissertation, Addis Ababa University. 


\section{Lutz Edzard}

SteTKeVych, Jaroslav. 1970. The Modern Arabic Literary Language: Lexical and Stylistic Developments. Chicago: Chicago University Press.

UssishKIN, Adam 1999. "The inadequacy of the consonantal root: Modern Hebrew denominal verbs and output-output correspondence.” Phonology, 16: 401-442.

VersteEgh, Kees. 2001. The Arabic Language. 2nd edn. Edinburgh: Edinburgh University Press.

Page | 414

WeHr, Hans / J. Milton Cowan. 1994. A Dictionary of Modern Written Arabic: (Arabic - English). 4th ed., considerably enl. and amended by the author. Spoken Language Series. Urbana, IL: Spoken Language Services.

ZABORSKI, Andrzej. 1991. "Biconsonantal roots and triconsonantal root variation in Semitic: Solutions and prospects". In: KAYE (ed.) 1991, 2: 1675-1703.

(C) Lutz Edzard, University of Erlangen-Nürnberg/Germany | University of Oslo/Norway \1.e.edzard@ikos.uio.no, lutz.edzard@fau.de • 